\title{
Ex-situ Conservation of Crops through Vertical Pink Farms
}

\section{Iqra Rehmani ${ }^{1}$, Srinath Pandey ${ }^{1}$, Ved Kumar Mishra ${ }^{1}$, Swati Dwivedi', Shubhangi Dixit ${ }^{1}$ and Prashant Ankur Jain ${ }^{2}$}

${ }^{1}$ Department of Biotechnology, Naraina Vidya Peeth Engineering and Management Institute, [Affiliated to Dr A P J Abdul Kalam Technical University (AKTU Code-429),

Lucknow, Uttar Pradesh, India], Naraina Group of Institution,

Gangaganj, Panki, Kanpur, Uttar Pradesh, India-208020

${ }^{2}$ Department of Computational Biology and Bioinformatics,

Jacob School of Biotechnology and Bioengineering, Sam Higginbottom University of

Agriculture, Technology and Sciences (SHUATS), Allahabad, U.P., India-211007

*Corresponding author

\section{A B S T R A C T}

One of the recent innovations in the field of agriculture is Pink Farming. It is a ex-situ farming technique using pink colored illumination for the cultivation of crops. This pinkcolored light is a mixture of red and blue lights from LEDs (Light Emitting Diodes). are being converted into vertical pink farms are made by transformation of large warehouses located in the suburbs of the cities, growing crops arranged in shelves, top to bottom, one over other. Japan has the World's biggest indoor vertical pink farm, Mirai Co. is situated at Japan. Visible light spectrum (V-I-B-G-Y-O-R) is constituted of seven different colors of different wavelengths. However, plant photosynthetic machinery absorbs wavelengths of red $(630 \mathrm{~nm}-750 \mathrm{~nm})$ and blue light $(450 \mathrm{~nm}-490 \mathrm{~nm})$ efficiently. Since, red light promotes plant elongation and blue light enhances metabolites in crops. LEDs used in the pink-houses are cooler than the HPS (High - Pressure Sodium) lamps used in greenhouses, so they can be placed in the vicinity of plants. They have low power consumption, high brightness and nominal heat generation. Parameters such as water level, $\mathrm{CO}_{2}$ level, nutrient level, lighting, temperature and humidity can be precisely controlled in a vertical pinkhouse. Pink-houses can cultivate nutrient - dense, seasonal crops as well as medicinal plants all year round. A pink-house shows $20 \%$ faster growth rates in plants and $75 \%$ less energy consumption as compared to a greenhouse. Plants in a pink-house do not require sunlight or natural rainfall and are grown without the use of chemical fertilizers or pesticides.

\section{Introduction}

\section{Prologue to vertical pink farming}

Recent innovations in organic farming strategies such as pink farming has revolutionised agricultural technology. Pink farming is a expandable sustainable ex-situ farming technique that cultivates crops utilizing pink-colored illumination (Bridgette, 2013). A major problem with vertical farming is sunlight. In a vertical farm, plants are 
stacked on top of each other in shelves. The alternative to this is to illuminate it with artificial lights (Michaeleen, 2013). Vertical pink farms can employ blue and red LEDs (Light Emitting Diodes) to cultivate organic, climate-controlled, temperature-modulated and pesticide-free crops indoors without the necessity of real sunlight (Gray, 2013). 'Pinkhouses' used for growing plants fluoresce magenta or pink from the blend of blue and red LEDs (Bridgette, 2013). Vertical farms can be worked up in large warehouses situated in the outskirts of the cities, where real-estate and electricity costs less (Abbie Stutzer, 2013). Engineers and Architects have extended the concept of skyscrapers that could be turned into urban food centers of the next generation (Michaeleen, 2013). 2.2 million Plants are irradiated with pink light as a result of fusion of blue and red LEDs in a pink-house at Caliber Biotherapeutics, Bryan, Texas (Mark Prigg, 2013). LEDs are energyefficient and cost-effective and can be adjusted to specific wavelengths at the time of production. LEDs are cooler than HPS (HighPressure Sodium) lamps; they can be set in the vicinity of plants (Orion Jones, 2016). Pink farming is a sound choice for growing métier crops round the year, since it is competent in terms of energy and water consumption (Susan, 2012). This technique is burgeoning across Asia, Mongolia, Hong Kong, Mainland China and Russia (Kurt, 2015). Japan has the world's largest indoor vertical pink farm, Mirai Co. that raises 10,000 heads of lettuce per day which is 100 times more per square foot than conventional methodology (Greg, 2015) (Figs. 1 and 2).

\section{Visible light spectrum}

The visible light spectrum is the portion of electromagnetic spectrum perceptible to the human eye. There are seven colors in the visible light spectrum namely violet, indigo, blue, green, yellow, orange and red with wavelength ranging from $400 \mathrm{~nm}-700 \mathrm{~nm}$ (Kartik, 2013; Cohen, 2003) (Table 1).

Mechanism of stomatal opening and photosynthesis in plants

Stomatal openings are exterior orifices, featuring intracellular crevices present in leaves acting as a channel for gaseous exchange $\left(\mathrm{CO}_{2}\right.$ and $\left.\mathrm{O}_{2}\right)$ and even water vapors $\left(\mathrm{H}_{2} \mathrm{O}\right)$. The stomal opening and closing is regulated by a pair of Guard cells, having greater elasticity than the other epidermal cells (Swahney and Israel Zelitch, 1964; John Whitmarsh and Govindjee). Photosynthesis can be termed as a physicochemical process in autotrophs converting carbon dioxide (in the presence of sunlight, chlorophyll and water) into glucose and oxygen (Elhaddad et al., 2014). The guard cells regulate the opening and closing of stomata in response to the stimulus of light intensity, so stomatal conductance increases in red and blue light stimulus (Carl Freer, 2016).

\section{Importance of red and blue light in photosynthesis}

The plant photo system is tuned to absorb red and blue light of the visible spectrum more efficiently (Nishio, 2000). A wavelength of $450 \mathrm{~nm}$ (blue light) and $650 \mathrm{~nm}$ (red light) are absorbed at the upper surface of leaf by chlorophyll a and chlorophyll $b$, respectively due to the abundance of chloroplast cells in this region and also scattered by structures such as mitochondria, nuclei, ribosomes, starch grains and other plastids (David et al., 1965; and Suetsugu et al., 2014). The stomata open at the wavelengths of red and blue lights, while it remains closed at the wavelength of green light (Suetsugu et al., 2014). Opening of stomata caused by blue light is increased by the red light (Massa et al., 2008). 
Table.1 Wavelength ranges for monochromatic light (in nm) (John gray, 1919)

\begin{tabular}{|c|c|}
\hline Color & Wavelength Range (nm) $\boldsymbol{\lambda}$ \\
\hline Red & $630-750 \mathrm{~nm}$ \\
\hline Orange & $590-630 \mathrm{~nm}$ \\
\hline Yellow & $570-590 \mathrm{~nm}$ \\
\hline Green & $490-570 \mathrm{~nm}$ \\
\hline Blue & $450-490 \mathrm{~nm}$ \\
\hline Indigo & $420-450 \mathrm{~nm}$ \\
\hline Violet & $380-420 \mathrm{~nm}$ \\
\hline
\end{tabular}

Table.2 Advantages of pink farming over conventional farming

\begin{tabular}{|c|c|c|c|}
\hline Sr. No. & Basis & Pink Farming & Conventional Farming \\
\hline 1 & Space efficiency & $\begin{array}{l}\text { Vertical pinkhouses are space- } \\
\text { efficient, since plants are } \\
\text { stacked on top of each other in } \\
\text { shelves (Michaeleen, 2013) }\end{array}$ & $\begin{array}{l}\text { Conventional agricultural } \\
\text { farms are spread over a vast } \\
\text { area of land (Maurizio et al., } \\
\text { 2011) }\end{array}$ \\
\hline 2 & Use of pesticides & $\begin{array}{l}\text { Pesticide-free crops are grown } \\
\text { (Gray, 2013) }\end{array}$ & $\begin{array}{l}\text { Pesticides and chemical } \\
\text { fertilizers are sprinkled to } \\
\text { increase the yield of crops } \\
\text { (Tiziano et al., 2011) }\end{array}$ \\
\hline 3 & $\begin{array}{l}\text { Wavelength } \\
\text { adjustments }\end{array}$ & $\begin{array}{l}\text { LEDs used in pink houses can } \\
\text { be adjusted to specific } \\
\text { wavelengths required by the } \\
\text { plant photosystem (Orion, 2016) }\end{array}$ & $\begin{array}{l}\text { No wavelength adjustments } \\
\text { can be made in conventional } \\
\text { farming, since white light is } \\
\text { the source of illumination } \\
\text { having wavelengths ranging } \\
\text { from } 400 \mathrm{~nm}-700 \mathrm{~nm} \text { (Orion, } \\
\text { 2016) }\end{array}$ \\
\hline 4 & Growth rate & $\begin{array}{l}\text { Observed growth rate of plants } \\
\text { is } 20 \% \text { faster than in } \\
\text { conventional } \\
\text { (Michaeleen, 2013) }\end{array}$ & $\begin{array}{l}\text { Comparatively, slower } \\
\text { growth rate than pink farming } \\
\text { (Michaeleen, 2013) }\end{array}$ \\
\hline 5 & $\begin{array}{l}\text { Adjustment of other } \\
\text { parameters }\end{array}$ & $\begin{array}{l}\text { Parameters such as temperature, } \\
\text { nutrient level, water level and } \\
\mathrm{CO}_{2} \text { level can be precisely } \\
\text { controlled in a pink house } \\
\text { (Maurizio G et al., 2011) }\end{array}$ & $\begin{array}{l}\text { The environmental or natural } \\
\text { parameters cannot be } \\
\text { adjusted according to the } \\
\text { requirements of the crop } \\
\text { (Maurizio G et al., 2011) }\end{array}$ \\
\hline 6 & $\begin{array}{l}\text { Level of } \\
\text { sustainability }\end{array}$ & $\begin{array}{l}\text { More sustainable (Bridgette, } \\
\text { 2013) }\end{array}$ & $\begin{array}{l}\text { Less sustainable (Tiziano et } \\
\text { al., 2011) }\end{array}$ \\
\hline
\end{tabular}


Figure.1 Plants illuminated through pink LEDs in a pink farm

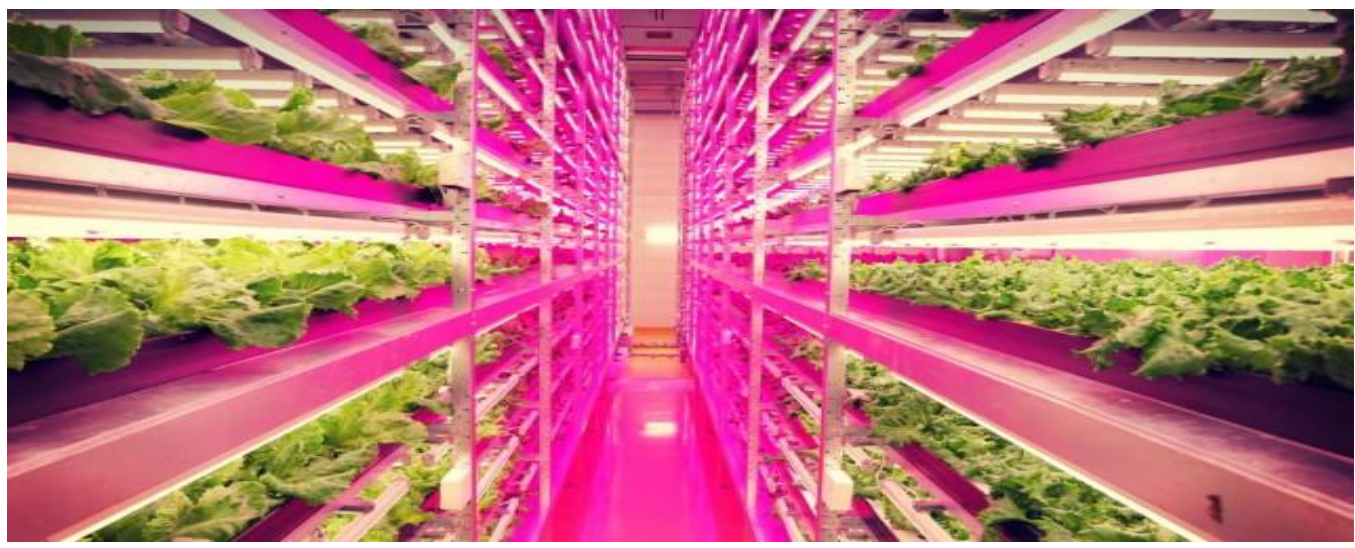

Figure.2 An illustration of vertical pink farm

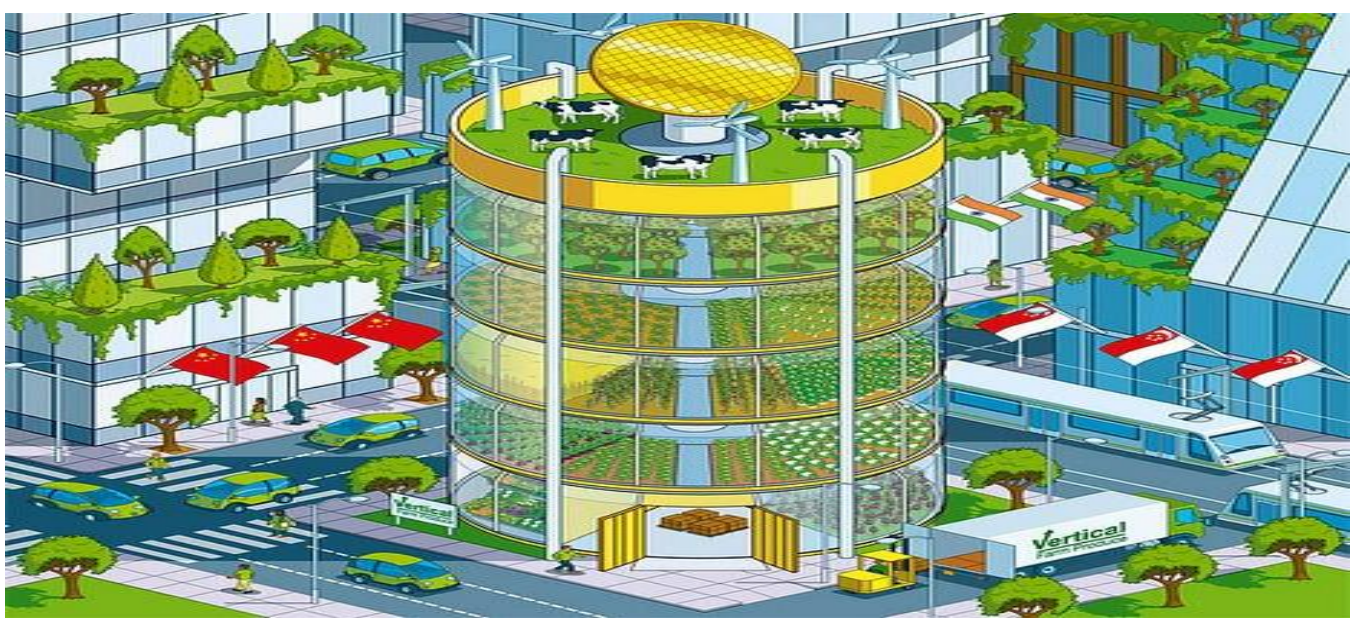

Figure.3 (a) Light spectrum; (b) Combination of various colors
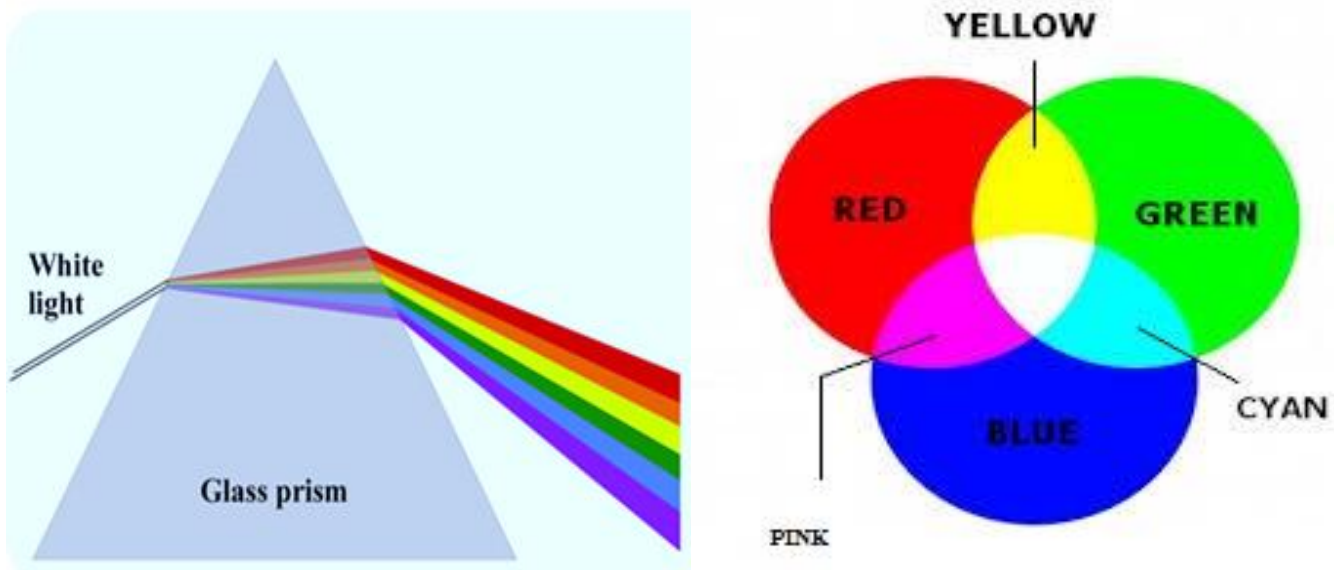
Figure.4 An illustration of stomatal cells

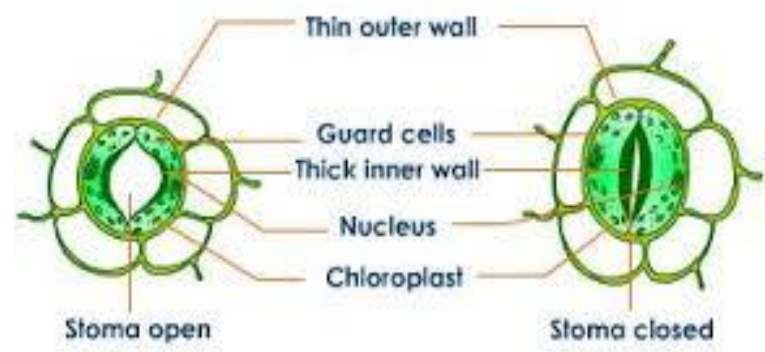

LEDs possess enormous potential as solesource of lighting or supplementary source of lighting for crop cultivation (Kamine, 2014). LEDs have longer life expectancy, low power consumption, high brightness, high endurance to humidity and nominal heat generation by lighting (Erik, 2016). Red light promotes plant elongation and favours flowering in some long- day plants (Dean et al., 2015). Concentrations of nutritionally significant metabolites are enhanced in crops by the blue light of LEDs (Sindy, 2014).

\section{Other aspects of pink farming}

Parameters such as water level, $\mathrm{CO}_{2}$ level, nutrient level, lighting, temperature and humidity can be incisively controlled in a pink house (Maurizio et al., 2011). Each shelf in a vertical pink house has its own water trickler that drizzles water into pans when needed and the excess water is also continuously recycled. A constant temperature is maintained and the lights turn on and off, imitating day and night according to the photoperiodicity of plants. Sensors detect missing nutrients and purvey them in precise amounts (Orion Jones, 2016; and Michaeleen, 2013). Pink houses are used to grow seasonal plants and other plants with medicinal values (Nishio, 2000). Nutrientdense crops such as tomatoes, yellow bell peppers, strawberries, basil, etc. can be cultivated in the shelves of a vertical pink house (Michaeleen, 2013) (Table 2).
In conclusion as a result of burgeoning world's population, there is an obvious surge in demands of nutrition. Vertical pink farms could resolve and address issues of water crisis and secure nutritional requirements. If the visible spectrum of light (V-I-B-G-Y-O$\mathrm{R}$ ), is divided into two regions through the green sector viz. the upper region and lower region. Upper region consisting of violet, indigo and blue wavelengths and the lower regions consisting of yellow, orange and red wavelengths, the red light has the maximum wavelength among all the colors and blue has the maximum wavelength in the upper region yielding to its consequent absorbance by plants. Therefore, red and blue lights are effectively absorbed by the plants, hypothesizing pink light absorbance. Future, vertical farms will be equipped with organic LEDs (or OLEDs) instead of LEDs to curb power consumptions in these organic farms or 'Plant scrapers', so that natural renewable source could meet energy requirements in these vertical pink farms (Figs. 3 and 4).

\section{Acknowledgement}

I would like to express heartiest gratitude towards the respected faculty members who have empowered me with the novel ideas and guided me during this unfamiliar challenge. A special vote of thanks to $\mathrm{Mr}$ Ved Kumar Mishra Sir and $\mathrm{Mr}$ Srinath Pandey Sir (Assistant Professor, Department of Biotechnology) for encouraging me to accomplish this alien task within in a matter of days. 


\section{References}

Abbie Stutzer. 2013. "Pretty (and sustainable) in Pink: is the future of Urban Farming Vertical Pinkhouses?"

Bridgette Meinhold. 2013. "Indoor Vertical Farm 'Pinkhouses' grow plants faster with less energy" (Online article23/05/2013) http://inhabitat.com/indoorvertical-farm-pinkhouses-grow-plantsfaster-with-less-energy/

Carl Freer. 2016. "The Future is Pink: Vertical Pink Farming harnesses technology to grow crops" by agreener life a greener world in Carl Freer, climate impacts, food crisis,food security, guest blog, vertical farming.

David, M., Gates, Harry, J., Keegan, John, C., Schleter and Victor, R., Weidner. 1965. Spectral properties of plants in Appl. Optics, Vol. 4, Issue 1, pp. 11-20.

Dean, A., Kopsell, Carl, E., Sams and Robert, C., Morrow. 2015. Blue wavelengths from LED lighting increase Nutritionally important Metabolites in Specialty Crops. Hort. Sci., 50: 12851288.

Elhaddad, N.S., Hunt, L., Sloan, J., Gray, J.E. 2014. Light-Induced Stomatal Opening Is Affected by the Guard Cell Protein Kinase APK1b. PLoS ONE, 9(5): e97161.

doi:10.1371/journal.pone.0097161

Erik Runkle. 2016. "Red light and Plant growth" Technical Speaking in GPNMAG (Production), pp-50.

Gray Scott. 2013. "Seven Emerging Technologies that will change the World forever". (Online article-31-122015),

http://ieet.org/index.php/IEET/more/sco tt20150929

Greg Palsbo. 2015. "A snapshot of the future: Indoor farms". (Online article-28-012015).

Howard, L., Cohen. AST 1002 Study Guide
University of Florida 1999- 2003. http://www.astro.ufl.edu/ cohen/ast100 2/studguid.html

John Gray, George, J., Peirce. 1919. The influence of light upon the Action of Stomata and its relation to the transpiration of certain grains in American J. Bot., Vol. 6, No. 4, pp. 131-155.

John Whitmarsh, Govindjee. The Photosynthetic Process in "Concepts in Photobiology: Photosynthesis and Photomorphogenesis.

Kartik, R., Patel and Dhrubo Jyoti Sen. 2013. "V-I-B-G-Y-O-R of Chemistry: A journey from micro to macro world" Int. J. Drug Dev. Res., 5(3): 87-94

Komine, J. and Nakagawa, M. 2004. Fundamental analysis for visible light communication system using LED lights. Published in: IEEE Transactions on Consumer Electronics, (Volume: 50, Issue: 1) Page(s):100-107.

Kurt. 2015. "World's largest indoor farm is 100 times more productive". (Online Article by Kurt, filed under Offices and Commercial in the Architecture category, 11/01/2015).

Mark Prigg. 2013. “Are giant 'Pinkhouses' the future of Urban Farming? Warehouses could be turned into yearround farms using artificial light". (Online article-22-05-2013), http://www.dailymail.co.uk/sciencetech/ article-2329017/Is-pink-lighting-futurefarming-Researchers-revealbreakthrough-growing-using-artificiallights.html

Massa, G.D., Hyeon-Hye Kim, Raymond, M., Wheeler and Cary, A. "Mitchell. Plant Productivity in Response to LED Lighting" Hortsci., vol. 43(7): pp. 19511956.

Maurizio, G., Paoletti, Tiziano Gomiero and David Pimentel. 2013. "Introduction to the Special Issue: Towards a more 
Sustainable Agricultur", Crit. Rev. Plant Sci., 30: 2-5.

Michaeleen Doucleff. 2013. "Vertical 'Pinkhouses': The future of Urban Farming?" (Online article-21/05/2013).

Nishio, J.N. 2000. Why are higher plants green? Evolution of the high photosynthetic pigment complement in Plant Cell and Environ., 23: 539-548

Orion Jones. 2016. "Futuristic farming: A Green Revolution turned Pink". (Online article-2016), http://bigthink.com/ideafeed/indoorfarming-a-second-green-revolution

Sindya, N., Bhanoo. 2014. Indoor Farming might help feed millions, or at least make millions.

Suetsugu, N., Takami, T., Ebisu, Y., Watanabe, H., Iiboshi, C., et al. 2014. Guard Cell Chloroplasts Are Essential for Blue Light-Dependent Stomatal Opening in Arabidopsis. PLoS ONE, 9(9): e108374. doi:10.1371/journal.pone. 0108374

Susan Kraemer. 2012. "Pink LEDs grow Future Food with $90 \%$ less Water in Green Tech and Gadgets". (Online article-29-02-2012).

Swahney, B.L. and Israel Zelitch. 1964. Direct determination of Potassium ion accumulation in Guard Cells in relation to the Stomatal opening in light in Plant Physiol., 44: 1350-1354.

Tiziano Gomiero, David Pimentel and Maurio, G., Paoletti. 2011. Environmental impact of different Agricultural Management Practices: Conventional vs. Organic Agriculture. Pages: 95-124, Published online: 29 April 2011.

\section{How to cite this article:}

Iqra Rehmani, Srinath Pandey, Ved Kumar Mishra, Swati Dwivedi, Shubhangi Dixit and Prashant Ankur Jain. 2017. Ex-situ Conservation of Crops through Vertical Pink Farms. Int.J.Curr.Microbiol.App.Sci. 6(4): 727-733. doi: https://doi.org/10.20546/ijcmas.2017.604.089 